ARTICLE

\title{
What Role Does School Play in Helping Socioeconomically Disadvantaged Students Succeed against the Odds?
}

\author{
Pingping Zhang, Yongmei Hu \\ Zhengzhou University, Zhengzhou, China \\ Beijing Normal University, Beijing, China
}

\begin{abstract}
Based on the data of a large scale survey conducted by Collaborative Innovation Center of Assessment Toward Basic Education Quality at Beijing Normal University, this study examined the role of school in reducing education inequality. The results showed that schools concentrated with resilient students had higher mean socioeconomic status (SES) and SES heterogeneity, more education resources, higher teaching quality, and more positive school climate, and these factors also functioned as significant predictors of academic resilience. Providing socioeconomically disadvantaged students with access to both high SES schools and enriched school resources can even the education inequality related to family background. In order to promote education equality, policymakers and education practitioners should take measures to reduce the degree of stratification and encourage student integration, promote equal distribution of high quality education resources among schools, enhance teachers' ability to effectively use individualized, cooperative and inquiry teaching methods, and build a supportive climate.
\end{abstract}

Best Evid Chin Edu 2019; 2(2):243-263.

Doi: 10.15354/bece.19.ar1051

Keywords: Socioeconomic Status; Disadvantaged Students; Resilient Students;

Educational Outcome Equity

Correspondence to: Yongmei Hu, Professor, Faculty of Education, Beijing Normal University, Beijing, China. Email:hym0718@163.com

About the Author Pingping Zhang, lecturer and postdoctoral researcher at Department of Education, Zhengzhou University, Zhengzhou, China. Email:zppcandy@163.com

Conflict of Interests: None. 


\section{Introduction}

INCE the release of Coleman Report in 1966, the impact of schools on students' achievement and education inequality has been a hot topic in educational sociology and educational economics. It has been widely studied regarding the role of schools in students' academic development and in education inequality, and formed distinct views such as schools can reproduce and expand education inequality, or schools can compensate for the cognitive gap between students with different family backgrounds (Raudenbush \& Eschmann, 2015).

Regarding school's role in promoting education inequality has been dominating contemporary sociology of education, because it was recognized that schools enlarge the learning outcome inequality, which consequently expands social inequality. However, accumulating empirical studies revealed that educational inequality, in some other aspects such as the gap between students' academic achievement, cognitive and noncognitive skills is strongly related to family socioeconomic status (SES), in which schools had much larger compensation effect than expected (Alexander, et al., 2001; Downey, et al., 2004; Downey \& Condron, 2016; Ready, 2010). As the resource substitution theory indicated that the existence of multiple resources makes the outcomes less dependent on any particular resource, i.e., in an individual's development, one type of resource can compensate the other that was absent (Ross \& Mirowsky, 2006). For students from low SES families, they are at a prominent disadvantage in the possession of family economic, cultural and social capital, their academic performances would largely depend on the accessible school resources, so they would benefit more from schools where the quality improved. In other words, access to high-quality school will make up the negative impact resulted from the lack of family resources. Accordingly, the chance for individuals with disadvantaged family background to become academically resilient students $\underline{\underline{1}}$ will be significantly increased if the school quality improved. Based on the basic theoretical model of education effectiveness research proposed by Klieme et al. (2014), this study aimed to explore the influence of school input and process factors such as the composition of school, school resources, teaching quality, and school climate on disadvantaged students' academic resilience, and to test the applicability of "resource substitution theory" in the school education outcomes.

\section{Literature Review}

Based on the educational production function, studies analyzed the role of school factors that affect students' development under the theoretical frame as "background - input - process - output", of which the factors include school composition, school resources, teaching quality and school environment (Borman \& Dowling, 2010; Du \& Yang, 2012; OECD, 2005; Ren \& Xin, 2011; Xie \& Zhang, 2018).

\section{School Composition and the Development of Disadvantaged Students}


As a result of residential segregation and the implementation of nearby enrollment policy, there is a distinct social class division between schools. Students from disadvantaged families are more likely to be enrolled in socioeconomically disadvantaged schools. The socioeconomic composition of a school reflects the degree of social class division, which is widely considered as an important factor to explain the difference in students' performance between schools. Investigation into the relationship between school composition and students' development provides an essential reference for education policy reform and practice.

School socioeconomic composition functions as an indicator for students' achievement that shows a significant heterogeneity. Studies have shown that the link between school socioeconomic composition and academic performance was stronger in disadvantaged students. From the data of the Second International Mathematical Comparative Study, Zimmer et al. (2000) found that the peer effect was significant enough to affect students' academic achievement for those who aged 13 to 14 years and especially for students with lower mathematical ability across five participating countries. Using the data of the Trends in International Mathematics and Science Study (TIMSS) 2011, Gustafsson (2016) found that, in most countries or regions, the average school SES was the most remarkable moderating variable of the relationship between family SES and the eighth grade students' achievement, which indicated that education system can somewhat compensate the education inequality that related to family background, and the most effective education system will help disadvantaged students to achieve better results through building up a safe, orderly and achievement-oriented school environment, as well as providing higher quality instruction. As reviewed by Anjani (2016) that the expansion of heterogeneity of students' SES within a school was more conducive to their development, that is, the integration of students from various social status can be a policy used to promote academic development of disadvantaged students.

However, contrast results from different studies had not found a definite relationship between school socioeconomic composition and academic performance. Rumberger et al. (2005) conducted a multilevel analysis on the data of National Education Longitudinal Study, and no significant difference was found regarding the impact of school SES on the academic achievement between advantaged and disadvantaged students. The descriptive study conducted by Perry et al. (2010) on the Australian PISA samples also found that the achievement gap between high and low SES schools was almost the same among different individuals with various SES levels.

In sum, the school composition has a heterogeneous effect on students' achievement, and providing disadvantaged students with opportunities for entering relatively higher SES and more heterogeneous schools is one of the ways to compensate for the lack of family education resources. However, direct evidence was yet found on this relationship. Based on relevant findings and the resource substitution theory, we hypothesized that,

- H1a: The higher the average SES for schools, the higher the probability that disadvantaged students would be resilient. 
- H1b: Disadvantaged students enrolled into high SES schools would significantly reduce learning outcome gap that was related to family background.

- H2a: The greater the SES heterogeneity for schools, the higher the probability that disadvantaged students would be resilient.

- H2b: Disadvantaged students enrolled into high heterogeneous SES schools would significantly reduce learning outcome gap that was related to family background.

\section{School Educational Resources and the Development of Disadvantaged Students}

Investigation into the effect of school educational resources on students' academic performance would provide a basis for the policy formulation to allocate resources and for the implementation of measures to promote a balanced development of education. In general, variables such as the average education expenditure, proportion of teachers who hold different types of degrees or qualifications, teachers' work experience, and school size were regarded as school education resources to carrying out survey and experimental studies, and then drawing certain type of relationship between these resources indicators and students' achievements.

It has showed that the heterogeneity of school education resources had substantial effect on students' achievement, and disadvantaged students who are lack of family resources would benefit more from the enriched school resources. At least three significant evidences support this relationship. First of all, the school quality has a bigger impact on students' performance in low-resourced countries. Heyneman and Loxley (1983) conducted a comparative study of 28 countries, and found that the effect of school education resources on elementary students' achievement displayed different patterns in different education systems (so-called "Heyneman-Loxley effect", HL effect), namely the lower the country's per capita income, the smaller the impact of family SES on students' achievement, the greater the impact of schools and teachers' quality on students' achievement. Baker et al. (2002) found that although HL effect has subsided somewhat, it still exists in those countries affected by extreme poverty, instability and infectious diseases. The most recent study conducted in the developing countries also verified that school resources had significant impact on students' performance (Ndlovu, 2018). Second, school education resources have significant impact on the academic performance of disadvantaged students. Based on the comparative data provided by PISA, Agasisti et al. (2014) used multilevel logit regression to find that the quality of school education resources, the proportion of qualified teachers, extra-curricular activities significantly improved the possibility of disadvantaged students to be resilient, whereas class size, computer per student were of little importance (Agasisti, et al., 2018). Based on the samples of the fourth to eighth graders, Southworth (2010) adopted multilevel linear regression to find that improving the quality of teachers and school resources reduced the influence of school ethnic composition and socio-economic composition on students' academic achievements indicating that school could compensate for disadvantaged students. Third, the influence of school educational resources on students with low SES is 
relatively greater. Studies have found that school educational resources have bigger impact on disadvantaged students than the advantaged peers, such as the positive effect of small-class teaching on minority students was more significant than white students (Finn \& Achilles, 1999), and teacher quality and student/teacher ratio had significant impact on the relationship between family SES and students' achievement (Hou \& Shen, 2014; Nye, et al., 2004). These results suggested that school educational resources play a compensating role in helping disadvantaged students to develop. However, few studies observed the heterogeneous effect of school resources on different groups of students, and more empirical evidence is needed regarding the impact of school resources on the academic development of disadvantaged students'.

Based on previous findings and the resource substitution theory, and to examine the impact of school education resources on the academic development of disadvantaged students, we hypothesized that,

- H3a: Access of disadvantaged students to schools with more sufficient educational resources would significantly increase their chances to become resilient students.

- H3b: Access for disadvantaged students to schools with more sufficient education resources would significantly reduce learning outcome inequality that was related to family background.

\section{Teaching Quality and the Development of Disadvantaged Students}

Observable teaching methods and teaching practices are important indicators of teaching quality, which represent middle-leveled learning opportunity and reflect a more authentic process of educational equity. Variables such as the frequency of teachers' use of cognitive activation, adaptive teaching, inquiry-based teaching methods, as well as classroom management, and classroom learning environment are used to indicate teaching quality, and correspondingly their impact on students' academic development was observed.

Studies have shown that teaching quality affects students' learning motivation and achievement, and high-quality teaching had a greater impact on students who were at risk of academic failure. Klieme et al. (2009) proposed a basic model including cognitive activation, classroom management and supportive climate, which assumed that cognitive activation influences students' mastering and understanding of knowledge through deep processing and self-reflection; structured and clearly-defined classroom management affects students' achievement through time on task; and supportive climate influences students' learning motivation through the mediation of mood and emotion. Studies based on data from the Tennessee STAR plan indicated that all four grade students can benefit from effective teaching, and evidence showed that the effect of teaching on math was more obvious in schools concentrated with minority students although the overall difference of genders, races or SES backgrounds was small (Konstantopoulos \& Chung, 2011). Studies of fourth grade students in six European countries found that the teacher factors in the education effectiveness dynamic model that includes structured teaching, questioning and problem solving, higher order prob- 
lem solving thinking skills, providing opportunities to practice and applicate new knowledge, quality of interaction between teachers and students, and formative learning assessment had much bigger impact on the academic achievements of students with low performance, but none of these factors had larger effect on students with good performance (Vanlaar et al., 2016). Studies of Latino students from low-income families showed that the flexibility and practicability of teaching had a positive effect on students' academic resilience (Sosa \& Gomez, 2012). Studies of elementary students in South American showed that, compared with non-resilient students, resilient students were more likely to report that teachers providing more feedback and teaching arrangements were reasonable (Waxman et al., 1997). Teaching strategies, such as group learning and encouraging each other, helped promote educational resilience (Downey, 2008). These results suggested that maximizing students' meaningful participation in the class through teachers' effective teaching is an important way to enhance academic resilience.

According to previous research findings, we hypothesized that,

- H4a: Disadvantaged students entering schools with better teaching quality would significantly increase their probability to become resilient students.

- H4b: Disadvantaged students entering schools with better teaching quality would significantly reduce learning outcome inequality related to family background.

\section{School Climate and the Development of Disadvantaged Students}

School climate is a relatively persistent and stable "soft environment" characteristic that distinguishes one school from the other. It is an important aspect of the school education process. It was described that school climate is the order and discipline, teacherstudent relationship, academic pressure, teachers' morale, etc., through which the correlation with students' academic development was investigated to provide reference for school-based improvement.

Studies have shown that positive school climate is protective to resilience and weakens the negative impact of family SES on students' achievements. Children exposed to risk factors would benefit from supportive school relationships and achieve sustainable academic success (Wang et al., 1998). A follow-up study of low-SES minority elementary students in the United States showed that a safe and orderly school environment and positive teacher-student relationship are contributors to distinguish resilient students from non-resilient ones (Borman \& Rachuba, 2000). A multilevel logit study based on PISA 2006-2015 data indicated that, for most participating countries and regions, schools with positive class environment were more likely to produce disadvantaged resilient students (Agasisti, et al., 2018). A study of American 15-year-old students found that the correlation between SES and student achievements in an orderly classroom condition was weaker than that from a negative condition (Cheema \& Kitsantas, 2014). A multilevel regression study of Israel's nationally representative sample of elementary and middle schools suggested that, school climate has a compensating and moderating effect for the relationship between school SES and students' 
achievements, which could be described as the achievement gap between students with different family backgrounds is much smaller under positive school climate condition (Berkowitz, et al., 2015). In addition, a meta-analysis of 78 studies on school/classroom climate and students' academic performance from 2000 to 2015 showed that positive school and class climate reduced the negative impact of low SES on academic performance (Berkowitz, et al., 2017). These findings suggested that the positive school climate contributed to the academic development of disadvantaged students and reduced educational inequalities related to family background.

In sum, supportive school and class climate has positive impact on students' academic performance and narrows the academic gap among schools and students with different socio-economic status. Therefore, we hypothesized that,

- H5a: Disadvantaged students entering a school with positive learning climate would increase their probability to become resilient students.

- H5b: Access of disadvantaged students to schools with positive learning climate would reduce outcome inequality related to family background.

\section{Methods}

\section{Data}

The data were from the "Regional Assessment of Education Quality" project jointly carried out by Collaborative Innovation Center of Assessment toward Basic Education Quality at Beijing Normal University and an eastern province in 2014. Stratified threestage unequal probability sampling method was adopted to select the fifth and ninth grade students, their parents, teachers and principals from 11 cities in the participating province for the academic test or survey. The project collected data of students' moral behavior, physical and mental health, academic development, interests and academic burden as well as information regarding their families and schools. A total of 30,743 grade 9 students from 610 junior high schools were enrolled in this study. Among them, $84.6 \%$ were public schools and $15.4 \%$ were private schools. Urban schools accounted for $22.5 \%$, county-level schools were $27.9 \%$, and rural schools were about $49.7 \%$. Besides, $48.7 \%$ were female students, $52.8 \%$ were from one-child families, and $92.7 \%$ had received more than one year of preschool education.

\section{Variables}

The school characteristic variables (Table 1) include: i) mean school SES and SES heterogeneity that reflect student composition and peer group characteristics; ii) school education resources including the adequacy of various teaching materials, courses and extracurricular activities that reflect the educational input; iii) school teaching quality including the use of individualized, cooperative and inquiry teaching strategies that reflects the learning opportunities; iv) school climate that reflects the learning environment. 
Table 1. Variables.

\begin{tabular}{|c|c|}
\hline Variable & Explanation \\
\hline SES Category & $\begin{array}{l}\text { The mean of parents' highest education level, parents' highest oc- } \\
\text { cupational status and family property score was calculated after } \\
\text { standardization and converted into a variable of } 0-10 \text {. Then, accord- } \\
\text { ing to the criteria of top/bottom } 1 / 3 \text {, it was divided into disadvan- } \\
\text { taged students, average students and advantaged students. }\end{array}$ \\
\hline $\begin{array}{l}\text { Academic Achieve- } \\
\text { ment }\end{array}$ & $\begin{array}{l}\text { Students' standardized test scores of Chinese, mathematics and } \\
\text { science are averaged after standardization, and then converted into } \\
\text { variables of } 0 \text { to } 100 \text {. }\end{array}$ \\
\hline Academic Resilient & $\begin{array}{l}\text { Firstly, the residuals of the regression of academic achievement on } \\
\text { SES and SES square terms are regarded as academic resilience. } \\
\text { Then, academic resilience was classified into high, medium and low } \\
\text { performance by top/bottom } 1 / 3 \text { standard. Finally, the top } 1 / 3 \text { group } \\
\text { was defined as resilient students, and the bottom } 1 / 3 \text { group was } \\
\text { defined as non-resilient students. }\end{array}$ \\
\hline Gender & Girl=1, Boy=0. \\
\hline Age & Calculated according to the date of birth of the student report. \\
\hline Only Child & Single child in the family $=1$, others $=0$. \\
\hline Preschool Education & 1 year or more preschool education $=1$, less than 1 year $=0$. \\
\hline School Mean SES & Mean of students' family SES in the school. \\
\hline SES Heterogeneity & Standard deviation of students' family SES in the school. \\
\hline $\begin{array}{l}\text { Educational Re- } \\
\text { sources }\end{array}$ & $\begin{array}{l}\text { The scores of the adequacy of school infrastructure and teaching } \\
\text { materials, extracurricular activities and school-based courses are } \\
\text { standardized and averaged, and then converted into a variable of } 0 \text { - } \\
10 \text {. }\end{array}$ \\
\hline Teaching Quality & $\begin{array}{l}\text { The mean of students' evaluation about teachers' individualized, } \\
\text { collaborative and inquiry teaching, which is converted into a variable } \\
\text { of } 0-10 \text { at the school level. }\end{array}$ \\
\hline School Climate & $\begin{array}{l}\text { The mean of students' evaluation about teachers' behavior in re- } \\
\text { spect, trust, fairness and justice, which is converted into a variable } \\
\text { of } 0-10 \text { at the school level. }\end{array}$ \\
\hline Public/Private School & Private $\mathrm{school}=1$, public $\mathrm{school}=0$. \\
\hline School in the City & School in the city $=1$, others $=0$. \\
\hline School in the County & School in the county $=1$, others $=0$. \\
\hline School Size & Total school enrollment/100. \\
\hline
\end{tabular}

As showed in the Table 2, for the whole sample, the mean of students' academic performance and academic resilience were 65.156 and 59.183, respectively. The average age was 14.455. The means of school SES, SES heterogeneity, educational resources, teaching quality and school climate were 4.271, 1.344, 6.793, 5.063 and 5.111, respectively. The average enrollment of schools was 1,198. For the sub-samples, the mean academic performance of disadvantaged students was significantly higher than that of non-disadvantaged students, and the average age of disadvantaged students was significantly higher than non-disadvantaged ones. Advantaged schools had highest $\underline{\underline{2}}^{\underline{2}}$ score in mean SES, SES heterogeneity, educational resources, teaching quality, school 


\section{Table 2. Descriptive Statistics.}

\begin{tabular}{|c|c|c|c|c|c|c|c|}
\hline & \multirow{2}{*}{ Variable } & \multicolumn{2}{|c|}{ Full Sample } & \multicolumn{3}{|l|}{ Split Sample } & \multirow{2}{*}{$F$} \\
\hline & & $\mathbf{M}$ & SD & Disadvantaged & Avg & Advantaged & \\
\hline \multirow[t]{2}{*}{ Stdt } & $\begin{array}{l}\text { Academic } \\
\text { Achievement }\end{array}$ & 65.16 & 17.37 & 58.39 & 65.15 & 72.11 & $1,823.02^{* * \star}$ \\
\hline & Age & 14.46 & 0.63 & 14.56 & 14.45 & 14.36 & $253.86^{* *}$ \\
\hline \multirow[t]{6}{*}{ Schl } & $\begin{array}{l}\text { Schl Mean } \\
\text { SES }\end{array}$ & 4.27 & 1.16 & 3.13 & 4.05 & 5.64 & $1,217.74^{* \star \star}$ \\
\hline & $\begin{array}{l}\text { SES Hetero- } \\
\text { geneity }\end{array}$ & 1.34 & 0.27 & 1.11 & 1.33 & 1.59 & $331.59^{\star \star \star}$ \\
\hline & $\begin{array}{l}\text { Edu Re- } \\
\text { sources }\end{array}$ & 6.79 & 1.90 & 5.75 & 6.89 & 7.73 & $67.37^{\star \star \star}$ \\
\hline & $\begin{array}{l}\text { Teaching } \\
\text { Quality }\end{array}$ & 5.06 & 1.48 & 4.42 & 5.07 & 5.71 & $44.12^{\star \star *}$ \\
\hline & $\begin{array}{l}\text { Schl } \\
\text { Climate }\end{array}$ & 5.11 & 1.37 & 4.63 & 5.09 & 5.61 & $28.08^{\star \star * *}$ \\
\hline & School Size & 11.98 & 8.30 & 7.50 & 12.81 & 15.62 & $59.68^{* \pi / 2}$ \\
\hline
\end{tabular}

climate and school size; schools with middle-level status scored the second high; and disadvantaged schools scored the lowest in all school factors.

The overall development of disadvantaged students' was in general worse than those from the average and advantaged families, and the quality index of disadvantaged schools was significantly lower than advantaged schools reflecting the idea that family background has significant effect on children's human capital accumulation. The uneven distribution of education resources between different schools was an important mechanism of the education inequality. These differences demonstrated the problems that disadvantaged students might have, and these differences within this group provide potential key to solve the development problems. Therefore, we, in this study, explored the school factors associated with disadvantaged students with different academic development outcomes (resilient versus non-resilient), and explained how schools provide educational compensation for disadvantaged students.

\section{Statistical Analysis}

Multivariate analysis of variance (MANOVA) was used to explore the characteristic differences among schools with different proportions of resilient students; multilevel logit regression was used to explore the influence of school factors on the odds ratio (OR) of disadvantaged students becoming resilient, and multilevel linear regression was used to explore which school factors narrow the achievement gap between students with different family background. All analyses were conducted in Stata13.0.

\section{Results}




\section{Characteristics of the Schools with Different Proportion of Resilient Students}

In order to illustrate the relationship between schools and the academic resilience of disadvantaged students, we first analyzed the characteristics of schools with different ratios of resilience students. Schools were divided into three groups according to the proportion of disadvantaged resilient students, i.e., low resilient schools, medium resilient schools and high resilient schools. School grouping was the independent variable and the five characteristics were dependent variables. Through MANOVA and post hoc tests, we examined the differences among different groups of schools. The judgment rules of mean difference effect size (Cohen's d) listed by Pu (2014) (|0.2|, |0.5|, |0.8| represent small, medium, and large effects, respectively) were taken as the criteria for comparisons among different school groups. The results are presented in the Table 3. It showed that different school groups had significant differences in all the characteristic variables $(\mathrm{p}<0.001)$, and the score of high resilient schools was higher than that of medium and low resilient schools.

The average SES of high resilient schools was significantly higher than that of medium and low resilient schools and the effect size was 1.233 and 1.434 , respectively. The SES heterogeneity of high resilient schools was significantly higher than that of medium and low resilient schools and the effect size was 0.152 and 0.214 , respectively. The education resource adequacy at high resilient schools was significantly higher than that of medium and low resilient schools and the effect size was 0.449 and 0.564 , respectively. The teaching quality of high resilient schools was significantly higher than that of medium and low resilient schools and the effect size was 0.346 and 0.550 , respectively. The school climate of high resilient schools was significantly higher than that of medium and low resilient schools and the effect size was 0.220 and 0.247 , respectively.

These results indicated that, the quality of high resilient schools was significantly higher than both medium and low resilient schools, which manifested as higher average SES, greater SES heterogeneity, more education resources, higher teaching quality and more positive school climate. This is consistent with previous studies. In terms of the socio-economic composition of school, study based on the national assessment of educational progress data in the United States found that, the school SES of high performing African-American eighth graders was much higher than that of the low achieving students (Lee, et al., 1991). Based on the PISA 2006 data, study was conducted and found that the average economic, social and cultural status of the schools attended by resilient students was slightly higher than that of the disadvantaged low performing students (OECD, 2011). Based on the education quality assessment data in China, He et al. (2016) found that the average SES of fourth grade migrant children with high academic achievement was significantly higher than the migrant children with low academic achievement. In terms of school resources, a study of PISA 2009 Italian students found that the education resource quality of the schools with the lowest quarter of resilient students was significantly lower than other peer schools, and the difference in the extracurricular activity index was especially huge (Agasisti \& Longobardi, 2014). 
Table 3. Characteristics of Schools with Different Proportion of Resilient Students.

\begin{tabular}{|c|c|c|c|c|c|c|c|}
\hline \multirow{2}{*}{\multicolumn{2}{|c|}{ School group }} & \multirow[b]{2}{*}{ Stat. } & \multicolumn{5}{|c|}{ School Factors } \\
\hline & & & $\begin{array}{l}\text { Mean } \\
\text { SES }\end{array}$ & $\begin{array}{l}\text { SES } \\
\text { Hetero. }\end{array}$ & $\begin{array}{l}\text { Edu Re- } \\
\text { sources }\end{array}$ & $\begin{array}{l}\text { Teach } \\
\text { Quality }\end{array}$ & $\begin{array}{l}\text { Schl } \\
\text { Climate }\end{array}$ \\
\hline \multirow{2}{*}{\multicolumn{2}{|c|}{$\begin{array}{l}\text { Low Resilient } \\
\text { Schools }\end{array}$}} & Mean & 3.787 & 1.233 & 6.273 & 4.634 & 4.953 \\
\hline & & SD & 1.027 & 0.249 & 2.122 & 1.612 & 1.422 \\
\hline \multirow{2}{*}{\multicolumn{2}{|c|}{$\begin{array}{l}\text { Medium Resilient } \\
\text { Schools }\end{array}$}} & Mean & 3.912 & 1.306 & 6.587 & 4.991 & 4.998 \\
\hline & & SD & 0.817 & 0.257 & 1.659 & 1.262 & 1.298 \\
\hline \multirow{2}{*}{\multicolumn{2}{|c|}{$\begin{array}{l}\text { High Resilient } \\
\text { Schools }\end{array}$}} & Mean & 4.875 & 1.483 & 7.340 & 5.454 & 5.285 \\
\hline & & SD & 1.012 & 0.248 & 1.676 & 1.375 & 1.339 \\
\hline \multirow{2}{*}{\multicolumn{2}{|c|}{$\begin{array}{l}\text { Group } \\
\text { Difference }\end{array}$}} & $F$ & $76.313^{* * *}$ & $51.477^{* *}$ & $17.715^{* *+1}$ & $16.490^{* * *}$ & $3.499^{* * *}$ \\
\hline & & $\eta^{2}$ & 0.206 & 0.149 & 0.057 & 0.053 & 0.012 \\
\hline \multirow{4}{*}{$\begin{array}{l}\text { Post-hoc } \\
\text { Compar- } \\
\text { ison }\end{array}$} & \multirow[t]{2}{*}{$\begin{array}{l}\text { High- } \\
\text { Low }\end{array}$} & $\begin{array}{l}\text { Mean- } \\
\text { Difference }\end{array}$ & $1.088^{* * *}$ & $0.249^{* * *}$ & $1.068^{* * *}$ & $0.820^{* * *}$ & $0.333^{*}$ \\
\hline & & Cohen'd & 1.434 & 0.214 & 0.564 & 0.550 & 0.247 \\
\hline & \multirow{2}{*}{$\begin{array}{l}\text { High- } \\
\text { Medi- } \\
\text { um }\end{array}$} & $\begin{array}{l}\text { Mean- } \\
\text { Difference }\end{array}$ & $0.963^{* * *}$ & $0.177^{* * *}$ & $0.753^{* * *}$ & $0.463^{* *}$ & $0.287^{*}$ \\
\hline & & Cohen'd & 1.233 & 0.152 & 0.449 & 0.346 & 0.220 \\
\hline
\end{tabular}

Regarding teaching quality, a classroom observation study of schools concentrated with low family income Hispanic students in the US showed that, quantity and quality of theacademic interaction between teachers and students in the reading and mathematics classes (teachers took student-oriented teaching strategies such as cognitive guidance, cooperative learning, and understanding student at social and interpersonal levels) were the most influential variables of the academic results of low-income Hispanic students (Waxman, et al., 2008). On school climate, a study carried out in public schools in Canada found that resilient schools ("beating the odds schools") scored the 82nd percentile in the school climate, and the long-term underperforming schools scored in the 14th percentile; after accounting for a variety of factors such as characteristics of student organizations, school size and human resources, the climate of resilient schools was still more positive than the other schools (Voight et al., 2013), suggesting that school climate was an important distinguishing characteristic between "resilient school "and "non-resilient school".

\section{The Influence of School Factors on the Academic Resilience of Disad- vantaged Students}

We built up a series of two-level logistic regression models which included school average SES, SES heterogeneity, education resources, teaching quality and school climate as the key independent variables respectively to examine the influence of school factors on the academic resilience of disadvantaged students after accounting for the basic characteristics of students and schools. The results are shown in the Table 4. 
Table 4. The Influence of School Factors on the Possibility of Disadvantaged Students Becoming Resilient.

\begin{tabular}{|c|c|c|c|c|c|c|}
\hline Variables & Model 0 & Model 1 & Model 2 & Model 3 & Model 4 & Model 5 \\
\hline Gender & $\begin{array}{l}1.454^{* * x} \\
(0.087) \\
\end{array}$ & $\begin{array}{l}1.464^{* * *} \\
(0.079) \\
\end{array}$ & $\begin{array}{l}1.455^{* * *} \\
(0.078) \\
\end{array}$ & $\begin{array}{l}1.455^{* * *} \\
(0.078) \\
\end{array}$ & $\begin{array}{l}1.455^{* * *} \\
(0.078) \\
\end{array}$ & $\begin{array}{l}1.455^{* * \star} \\
(0.078) \\
\end{array}$ \\
\hline Age & $\begin{array}{l}0.822^{* * \star} \\
(0.035)\end{array}$ & $\begin{array}{l}0.822^{* * *} \\
(0.033)\end{array}$ & $\begin{array}{l}0.825^{* * *} \\
(0.033)\end{array}$ & $\begin{array}{l}0.821^{* * *} \\
(0.033)\end{array}$ & $\begin{array}{l}0.819^{\star * \star} \\
(0.033)\end{array}$ & $\begin{array}{l}0.82^{* * *} \\
(0.033)\end{array}$ \\
\hline Only Child & $\begin{array}{l}1.093 \\
(0.894) \\
\end{array}$ & $\begin{array}{l}1.064 \\
(0.058) \\
\end{array}$ & $\begin{array}{l}1.082 \\
(0.060) \\
\end{array}$ & $\begin{array}{l}1.084 \\
(0.060) \\
\end{array}$ & $\begin{array}{l}1.088 \\
(0.060) \\
\end{array}$ & $\begin{array}{l}1.09 \\
(0.060) \\
\end{array}$ \\
\hline $\begin{array}{l}\text { Preschool } \\
\text { Education }\end{array}$ & $\begin{array}{l}0.894 \\
(0.079) \\
\end{array}$ & $\begin{array}{l}0.867 \\
(0.073) \\
\end{array}$ & $\begin{array}{l}0.879 \\
(0.074) \\
\end{array}$ & $\begin{array}{l}0.889 \\
(0.075) \\
\end{array}$ & $\begin{array}{l}0.89 \\
(0.075) \\
\end{array}$ & $\begin{array}{l}0.891 \\
(0.075) \\
\end{array}$ \\
\hline City School & $\begin{array}{l}1.422^{*} \\
(0.250)\end{array}$ & $\begin{array}{l}0.485^{\star * \star} \\
(0.082)\end{array}$ & $\begin{array}{l}0.836 \\
(0.139) \\
\end{array}$ & $\begin{array}{l}1.192 \\
(0.190)\end{array}$ & $\begin{array}{l}1.275 \\
(0.203) \\
\end{array}$ & $\begin{array}{l}1.362 \\
(0.222) \\
\end{array}$ \\
\hline County School & $\begin{array}{l}1.671^{\star \star \star} \\
(0.249)\end{array}$ & $\begin{array}{l}0.813 \\
(0.102) \\
\end{array}$ & $\begin{array}{l}1.047 \\
(0.138) \\
\end{array}$ & $\begin{array}{l}1.562^{\star \star *} \\
(0.195)\end{array}$ & $\begin{array}{l}1.515^{\star \star \star} \\
(0.190) \\
\end{array}$ & $\begin{array}{l}1.618^{\star \star \star} \\
(0.209)\end{array}$ \\
\hline Private School & $\begin{array}{l}0.795 \\
(0.235) \\
\end{array}$ & $\begin{array}{l}0.807 \\
(0.125) \\
\end{array}$ & $\begin{array}{l}0.888 \\
(0.145) \\
\end{array}$ & $\begin{array}{l}0.894 \\
(0.149) \\
\end{array}$ & $\begin{array}{l}0.810 \\
(0.134) \\
\end{array}$ & $\begin{array}{l}0.793 \\
(0.134) \\
\end{array}$ \\
\hline School Size & $\begin{array}{l}1.023^{*} \\
(0.012)\end{array}$ & $\begin{array}{l}0.997 \\
(0.006) \\
\end{array}$ & $\begin{array}{l}1.008 \\
(0.006) \\
\end{array}$ & $\begin{array}{l}1.015^{\star} \\
(0.006)\end{array}$ & $\begin{array}{l}1.02^{\star *} \\
(0.006)\end{array}$ & $\begin{array}{l}1.022^{\star \star \star} \\
(0.007)\end{array}$ \\
\hline $\begin{array}{l}\text { School } \\
\text { Mean SES }\end{array}$ & & $\begin{array}{l}2.524^{* * x} \\
(0.185)\end{array}$ & & & & \\
\hline $\begin{array}{l}\text { SES } \\
\text { Heterogeneity }\end{array}$ & & & $\begin{array}{l}7.468^{* * *} \\
(1.706)\end{array}$ & & & \\
\hline $\begin{array}{l}\text { Education } \\
\text { Resources }\end{array}$ & & & & $\begin{array}{l}1.226 \\
(0.035)\end{array}$ & & \\
\hline Teaching Quality & & & & & $\begin{array}{l}1.293^{* \star *} \\
(0.048)\end{array}$ & \\
\hline School Climate & & & & & & $\begin{array}{l}1.144^{* * *} \\
(0.045)\end{array}$ \\
\hline Constant & $\begin{array}{l}11.079^{* * *} \\
(7.322)\end{array}$ & $\begin{array}{l}0.581 \\
(0.379)\end{array}$ & $\begin{array}{l}1.105 \\
(0.737)\end{array}$ & $\begin{array}{l}3.348 \\
(2.132)\end{array}$ & $\begin{array}{l}3.577^{*} \\
(2.275)\end{array}$ & $\begin{array}{l}6.004^{\star *} \\
(3.855)\end{array}$ \\
\hline $\mathrm{N}$ of Students & 7630 & 7630 & 7630 & 7630 & 7630 & 7630 \\
\hline $\mathrm{N}$ of Schools & 585 & 585 & 585 & 585 & 585 & 585 \\
\hline
\end{tabular}

According to model 0 (only control variables were included), gender, age, school location and school size had significant influence on the probability of disadvantaged students to become resilient, whereas the coefficient of single child or not, preschool education and private school were not significantly related to this probability. To be specific, the odds ratio of disadvantaged girls becoming resilient was 1.454 times higher than the disadvantaged boys; with one-year increase in age as unit, the odds ratio of disadvantaged students becoming resilient was decreased by $17.8 \%$. The odds ratio of disadvantaged students in urban schools and county-level schools to become resilient 
was 1.422 and 1.671 times higher than those from rural schools, respectively. For every additional 100 students in school size, the odds ratio of disadvantaged students becoming resilient increased by $2.3 \%$. These results indicated that, compared with their peers, male students, older students (who enrolled in school later than usual or have had repeated grades), rural school students and small school students were more likely to face the risk of academic failure caused by low family SES, so they need more attention being paid by their parents and educators.

According to models 1 to 5, after accounting for the effect of students and school characteristics, the five factors were all significant predictors of the probability of disadvantaged students becoming resilient, which could be understood as: i) for oneunit increase in the average school SES, the odds ratio of disadvantaged students becoming resilient (OR, the same below) increases by $152.4 \%$. ii) For one-unit increase in the SES heterogeneity of school, the OR increases by $646.8 \%$. iii) For one-unit increase in school education resources, the OR increases by $22.6 \%$. iv) For one-unit increase in the teaching quality of the school, the OR increases by $29.3 \%$. v) For every unit improvement of school climate, the OR increases by $14.4 \%$. Therefore, the hypotheses $\mathrm{H} 1 \mathrm{a}, \mathrm{H} 2 \mathrm{a}, \mathrm{H} 3 \mathrm{a}, \mathrm{H} 4 \mathrm{a}$ and $\mathrm{H} 5 \mathrm{a}$ were verified.

\section{The Role of School in Reducing Achievement Gap Related to Family Background}

For students in different SES groups, we set a series of multilevel linear regression models which contained the key explanatory variables at the school level including the basic characteristics of students and schools and family capital, so as to investigate the effect of each school factor on the academic performance of students. The results are shown in the Table 5. After accounting for the controlling variables, five school factors significantly and positively predicted each group's academic achievement indicating that junior high school students with different family SES all benefited from the improvement of school average SES, school SES heterogeneity, school education resources, teaching quality and school climate; and with the exception of school climate, the effect of the other four school factors on students' academic performance increased as family SES decreased.

In order to compare the difference between the effects of school factors on three groups of students, we used the method that was proposed by Lian (2017) that includes the interaction terms to test whether the disadvantaged or the advantaged group benefited more from school improvement. First, we introduced a dummy variable Di ( $\mathrm{Di}=1$ indicates disadvantaged group, and $\mathrm{Di}=0$ indicates advantaged group) to represent the student group. Second, we included the interaction terms of dummy variable Di and all independent variables in the multilevel linear regression equation. For example, the academic performance was the dependent variable, the school average SES was the core independent variable, we constructed the interaction term of the Di with all the controlling variables (gender, age, single child or not, preschool education; family economic capital, family cultural capital, family social capital; school location, private/public, school size) and school average SES in the equation. Third, we ran the re- 
Table 5. The Differential Impact of School Factors on Different Group of Students.

Split-Sample Regression

Test for coefficient difference

Variable

$\begin{array}{llll}\text { Full } & \text { Disadvantaged } & \text { Average } & \text { Advantaged } \\ \text { Sample } & \text { Students } & \text { Students } & \text { Students }\end{array}$

between disad-

vantaged and

advantaged

groups

\begin{tabular}{|c|c|c|c|c|c|}
\hline $\begin{array}{l}\text { Student Char- } \\
\text { acteristics }\end{array}$ & Included & Included & Included & Included & Included \\
\hline $\begin{array}{l}\text { School Char- } \\
\text { acteristics }\end{array}$ & Included & Included & Included & Included & Included \\
\hline $\begin{array}{l}\text { School Mean } \\
\text { SES }\end{array}$ & $\begin{array}{l}6.099^{* * *} \\
(0.299)\end{array}$ & $\begin{array}{l}6.539^{* * *} \\
(0.437)\end{array}$ & $\begin{array}{l}5.693^{* * *} \\
(0.361)\end{array}$ & $\begin{array}{l}4.673^{* * *} \\
(0.326)\end{array}$ & $\begin{array}{l}0.899^{*} \\
(0.444)\end{array}$ \\
\hline $\begin{array}{l}\text { SES Hetero- } \\
\text { geneity }\end{array}$ & $\begin{array}{l}14.21^{* *} \\
(1.397)\end{array}$ & $\begin{array}{l}12.840^{* *} \\
(1.568)\end{array}$ & $\begin{array}{l}12.473^{* * *} \\
(1.402)\end{array}$ & $\begin{array}{l}9.993^{* * *} \\
(1.357)\end{array}$ & $\begin{array}{l}0.033 \\
(1.259)\end{array}$ \\
\hline $\begin{array}{l}\text { Educational } \\
\text { Resources }\end{array}$ & $\begin{array}{l}1.547^{* * *} \\
(0.190)\end{array}$ & $\begin{array}{l}1.536 \\
(0.194)\end{array}$ & $\begin{array}{l}1.313^{* * *} \\
(0.201)\end{array}$ & $\begin{array}{l}1.024^{* * *} \\
(0.194)\end{array}$ & $\begin{array}{l}0.343^{*} \\
(0.157)\end{array}$ \\
\hline $\begin{array}{l}\text { Teaching } \\
\text { Quality }\end{array}$ & $\begin{array}{l}1.93^{* * *} \\
(0.224)\end{array}$ & $\begin{array}{l}1.768^{* * *} \\
(0.248)\end{array}$ & $\begin{array}{l}1.708^{* * *} \\
(0.226)\end{array}$ & $\begin{array}{l}1.628^{* * *} \\
(0.225)\end{array}$ & $\begin{array}{l}-0.082 \\
(0.207)\end{array}$ \\
\hline $\begin{array}{l}\text { School Cli- } \\
\text { mate }\end{array}$ & $\begin{array}{l}1.206^{* \star \star} \\
(0.238)\end{array}$ & $\begin{array}{l}0.908^{* \star \star} \\
(0.268)\end{array}$ & $\begin{array}{l}1.038^{\star \star *} \\
(0.209)\end{array}$ & $\begin{array}{l}1.114^{\star \star \star} \\
(0.236)\end{array}$ & $\begin{array}{l}-0.313 \\
(0.212)\end{array}$ \\
\hline $\mathrm{N}$ of Schools & 610 & 592 & 610 & 588 & 610 \\
\hline $\mathrm{N}$ of Students & 30,743 & 10,585 & 9,844 & 10,314 & 20,899 \\
\hline
\end{tabular}

Note: 1. Student characteristics include gender, age, family structure (only child of not), preschool education as well as family economic capital, cultural capital and social capital; school characteristics include school location, school size, private/public school.

$2{ }^{* * *}: p<0.001,{ }^{*}: p<0.01, *: p<0.05$.

3. Standard error in parentheses.

gression model and paid attention to coefficients of the interaction of Di and the core independent variable. In the example above, the positive coefficient of the interaction term means that school average SES had a stronger effect on the academic performance in disadvantaged students; the negative coefficient of the interaction term indicates that school average SES had a stronger effect on the academic performance in advantaged student group. For the model with school SES heterogeneity, school education resources, school teaching quality and school climate as the core independent variables, the regression coefficient difference test of disadvantaged and advantaged students was also carried out according to the similar steps. The results are shown in the Table 5.

The coefficient of the interaction terms between schools' mean SES, school education resources and dummy variable were positively significant indicating that disadvantaged students gained more achievement benefits from the improvement of school average social status and school education resources. The coefficient of the interaction terms between SES heterogeneity, teaching quality, school climate and dummy variable were not significant, which indicated that disadvantaged students had basically the same achievement as disadvantaged students from the expansion of school SES heterogeneity, 
improvement of school teaching quality and improvement of school climate. Therefore, hypotheses $\mathrm{H} 1 \mathrm{~b}$ and $\mathrm{H} 3 \mathrm{~b}$ were verified, but hypotheses $\mathrm{H} 2 \mathrm{~b}, \mathrm{H} 4 \mathrm{~b}$ and $\mathrm{H} 5 \mathrm{~b}$ were not verified.

\section{Discussion}

\section{The Role of School Composition}

Based on the large scale survey data conducted by Collaborative Innovation Center of Assessment toward Basic Education Quality in China, our empirical study found that school average SES can be used to predict the probability of disadvantaged students to become resilient, as well as to narrow the education inequality related to family background, which confirmed previous findings such as "school socio-economic composition was significantly and positively related to students' academic performance" (Palardy, 2013; Perry, 2012) and "the average school SES could predict the possibility of disadvantaged students' academic resilience" (Agasisti, et al., 2018). Different explanations exist regarding the possible reasons why socio-economically disadvantaged students benefit from their peers who came from families with high SES. First, according to the endogenous effect of the social interaction (or social contagion effects) (Manski, 1993), peers' learning motivation and academic performance would directly influence student's academic achievement and to get them been more similar with their peers. Disadvantaged students who had peers with higher family SES generally developed higher self-education expectations (Wu \& Huang, 2010) and experienced fewer behavioral problems (Kahlenberg, 2012). Disadvantaged students in higher-SES classes or schools might face pressure from social norms to become more like their peers, thereby spending more time on their learning and achieving better results than expected. Second, socio-economically advantaged schools have more explicit and implicit resources such as higher-quality teachers, accumulated teaching and course resources, and potential resources from the community and parents as well. Disadvantaged students who were enrolled in these advantaged schools would automatically get access to these resources that would greatly compensate for the lack of family education resources. Third, in schools with higher SES, teachers there usually have higher expectations on students' performance, and then they would adopt higher standards for students and implement them in teaching. This kind of teaching strategy is beneficial to disadvantaged students. Fourth, disadvantaged students in higher-SES schools might receive more educational involvement from parents and more support from teachers, which would help them to develop positive psychological traits and valuable non-cognitive skills, thus achieve higher grades and narrow the achievement gap to advantaged peers.

Why does the increase of SES heterogeneity in school promote academic resilience of disadvantaged students? First of all, a significant positive correlation exists between the average school SES and SES heterogeneity. In our study, the correlation coefficient between them was 0.711. Disadvantaged students who were enrolled in heterogeneous schools have more relatively advantaged peers than those in the homogeneous schools. According to our explanations mentioned above, these students will benefit 
from the positive peer effects. Second, socioeconomic diversity reduces the negative impact of poverty on the brain. Continued pressure brought by poverty and fear would pass negative impact on the prefrontal executive function, and make individual's ability to solve problems, set goals and complete task be restrained (Wang \& Zhou, 2017). Relocating these disadvantaged individuals from persistent poverty pressure to schools with high integration of SES will produce positive results. Third, diversity promotes individual's cognition development. According to Piaget's cognitive development theory, children's cognition development is partially due to the imbalance of conflicts and diversity, and being in a diversified environment will promote individual's positive thinking ability, intellectual input and perspective formation, which contribute to good learning results (Conwayturner, 2016).

\section{The Role of School Education Resources}

This study found that the adequacy of school education resources positively predicted the probability of disadvantaged students for becoming resilient and reduced the educational inequality associated with family background indicating that school education resources indeed play a part in compensating for the development of disadvantaged students. This finding was consistent with the results on the effect of school curriculum and teaching resources. Using the PISA 2009 data of 15 EU countries, Agasisti et al. (2017) found that disadvantaged students who were enrolled in schools with more extracurricular activities and higher quantity and quality of resources were more likely to become academically resilient. Based on the data of Large-Scale Education Quality Assessment in China, He (2013) found that the student-teacher ratio and the number of math classes per week had a significant positive impact on the academic resilience of migrant and left-behind children. Students with low family SES gain significant benefit from adequate school education resources, probably because there may not have that much opportunity for them to participate in cultural activities at home, whereas the courses and extracurricular activities that schools provide can exactly help them to develop a sense of belonging and school identity, thus motivate them to learn more to improve academic performance and narrow the gap to the advantaged peers.

\section{The Effect of School Teaching Quality}

Our study revealed that the teaching quality of a school positively predicts the probability of disadvantaged students to become resilient, and provided new evidence that schools providing students with more meaningful learning opportunities such as differentiation, cooperation and inquiry learning could successfully cultivate academic resilience (Wang, et al., 1998). Using differentiating teaching strategy, the teachers have the opportunity to know their students more such as their difference/gaps in proficiency, ability to understand and knowledge use, learning interests and quality, and set up more appropriate teaching goals and use more reasonable teaching schedule to guide each individual student accordingly. With the help of teachers, the academic difficulties faced by disadvantaged students will be solved to a large extent, their confidence in learning and their motivation to explore new knowledge are also greatly promoted, 
which are helpful to give a full play to their potential and make their academic performance more reliant on their own effort. Using cooperative teaching strategy, students have more opportunities to discuss and communicate, and establish close relationship with their peers and teachers, and then their abilities to communicate, listen and cooperate, and their initiative, creativity and sense of competence all are greatly improved. A democratic and harmonious learning climate helps students to develop a more positive emotional attitude to schools and learning, and then put more effort in learning activities. Using inquiry-based teaching strategy, students have more opportunities to participate in activities such as raising questions, making assumptions, designing plans, analyzing results and drawing conclusions, and also have more opportunities to communicate, present and reflect that not only help to deepen their understanding of knowledge, but also cultivate their interpersonal skills. Inquiry-based classes can enhance students' autonomy and have been showing to be helpful to students' learning.

\section{The Effect of School Climate}

This study found that positive school climate is a significant predictor of the academic resilience of disadvantaged students, and provided new evidence that positive school climate is significantly correlated with academic success in low SES schools, and that support from important characters are the key reasons for them to achieve good performance. Studies on the relationship between school climate and academic success in public middle schools in Canada showed that students in schools with high school climate scores (top 5\%) were 10 times more likely to be resilient than those in schools with average scores (Voight, et al., 2013). In a meta-analysis of 99 articles about the correlation between teacher-student relationship and academic achievement ranging from pre-school to high school, the effect size of positive/negative teacher-student relationship and students' academic achievements was small to medium, and teacherstudent relationship had more influence on low SES students' academic achievement, and negative teacher-student relationship had more destructive influence on the academic development of students with learning difficulties or school failure risks (Roorda, et al., 2011). The resilience and youth development model that derived from ecological system theory assumed that teenagers have psychological needs such as safety, love and sense of belonging, and the fulfillment of these needs largely depends on the protective factors and resources provided by school, families, society, and peer groups (including close relationship, high expectations, and meaningful participation opportunity). If external resources are able to meet their psychological needs, individuals will develop resilient traits (such as cooperation, empathy and self-efficacy), and these traits will protect children from the adverse effects of the risk factors and help to obtain good development (Li \& Zhang, 2006). According to this model, positive school climate, serving as an external environment support, will help to satisfy students' basic needs such as building relationships, developing competence, and improving their psychological capital to cope with adversity, and becoming academically resilient.

\section{Implications}


From our study, we drew conclusions that showed significant differences in terms of school quality indicators between resilient and non-resilient schools, i.e., school quality indicators positively predicted the probability of disadvantaged students to become resilient, and school mean SES, school education resources significantly narrowed the achievement gap that related to family SES. Based on these, we put forward the following four suggestions to promote equal education.

\section{First, the Government and Educational Authority Should Try to Reduce the Social Class Division of Students and Promote the Integration of School Students.}

Governments and educational departments at all levels need to promote balanced development of compulsory education, strengthen the exchange and sharing of teachers, management experience, curriculum and resources between schools and different regions, narrow the gap in teachers and school conditions, even the imbalanced phenomenon of high SES student's concentration in some schools caused by school enrollment, and adjust the school social composition. In terms of school admission policy, we suggest the number of high SES students in quality schools must be strictly controlled, the access probability of disadvantaged students to quality schools must be increased to certain level to help them get more resources and supportive school environment, so that they can take advantage of these resources and environmental conditions to accelerate and narrow the achievement gap to their peers.

\section{Second, the Government and Educational Authority Should Increase In- vestment in Education Resources and Pay Attention to the Fairness of High-Quality Resources Distribution.}

Regarding educational resource investment, especially teachers' recruitment and supplement, governments at all levels should take into account the family background of students and give preference to schools with large number of disadvantaged students, so that making up the development gap between disadvantaged students in these schools and their advantaged peers. In addition, we also call for attention to the differences in school curriculum and extracurricular activities that potentially increase the achievement gap between schools. The local education department should try to provide afterschool services and high quality teaching resources for disadvantaged schools to ensure that high quality teachers and teaching resources are balanced and allocated, and gradually minimize the quality differences between schools.

\section{Third, Schools Should Try to Improve Teachers' Ability to Effectively Use Differentiated, Cooperative and Exploratory Teaching Methods.}

All kinds of schools, especially disadvantaged schools with a large number of disadvantaged students, should further deepen the reform of class teaching, and promote differentiated, cooperative and exploratory teaching methods to give all students the same 
opportunity to receive teachers' care, so that every student's learning needs can be met to a greater extent. Meanwhile, local education departments and schools should further intensify teacher's training in disadvantaged schools through establishing cross-regional teacher development community and research platform, and carrying out various kinds of teaching experience exchanges to improve teachers' ability to apply effective teaching strategies and gradually narrow the gap between teachers' professional abilities. All these measures help to promote students' achievement and narrow the gap between them resulted from the difference of family background.

\section{Fourth, Schools Should Try to Build Supportive School Climate.}

Teachers' support, especially for disadvantaged students, by paying attention to each student's development, encouraging their participation in the class, listening their needs, expressing respect, providing necessary help as well as giving high expectations, can improve students' school experience and enhance the sense of school belonging that subsequently help them to devote to learning. Besides, schools can provide appropriate feedback, recognition and rewards for teachers, motivate them to be dedicated to their jobs, and give them more opportunity of on-job training and further professional development, through which a solid foundation would be paved for improving the academic resilience of disadvantaged students

\section{Note:}

1. Students who encounter risk factors for academic failure (e.g., low family SES, migrant background, and ethnic minorities, etc.) but achieve much higher academic performance are called resilient students. For example, in the reports of PISA 2009, 2012, 2015 (program for international student assessment), the regression residual of students' performance on family economics, social and cultural statuses (ESCS) and ESCS square terms are used as indicators of academic resilience, and those with low ESCS and high academic resilience are defined as resilient students. In the thematic report of "education equity: breaking barriers to social mobility" released by OECD 2018, students with ESCS at the lowest 1/4 of their country/region and scores at the highest 1/4 of their country are defined as resilient students from the domestic perspective (OECD, 2018).

2. Disadvantaged schools were defined as having the lowest 1/3 of the average family SES, but advantaged schools were defined as having the top $1 / 3$ of the average family SES.

\section{References}

Agasisti, T. \& Longobardi, S. (2014) Inequality in education: Can Italian disadvantaged stu- dents close the gap? J Behav Exp Econ,

52(1): 8-20. 
Agasisti, T., Avvisati, F. \& Borgonovi, F. et al. (2018) Academic resilience: What schools and countries do to help disadvantaged students succeed in PISA. OECD Education Working Papers, No. 167.

Agasisti,T.,\& Longobardi, S. (2017) Equality of educational opportunities, schools' characteristics and resilient students: An empirical study of EU-15 countries using OECD-PISA 2009 Data. Soc Indic Res, 134(3): 1-37.

Alexander, K.L., Entwisle, D.R. \&Olsen, H.R. (2001) Schools, achievement, and inequality: A seasonal perspective. Educ Eval Policy An, 23(2): 171-191.

Anjani, K. (2016) Conversations in education reform: Socioeconomic integration as a tool for student success. Gett Soc Sci Rev, 1(1): 46-64.

Baker, D.P., Goesling, B. \&Letendre, G.K. (2002) Socioeconomic status, school quality, and national economic development: A cross-national analysis of the "HeynemanLoxley Effect" on mathematics and science achievement. Comp Educ Rev, 46(3): 291312.

Berkowitz, R., Glickman, H. \&Benbenishty, R. et al. (2015) Compensating, mediating, and moderating effects of school climate on academic achievement gaps in Israel. Teach Coll Rec, 117(4): 1-34.

Berkowitz, R., Moore, H. \&Astor, R.A. et al. (2017) A Research synthesis of the associations between socioeconomic background, inequality, school climate, and academic achievement. Rev Educ Res, 87(2): 425-469.

Borman, G.D., \& Dowling, M. (2010) Schools and inequality: A multilevel analysis of Coleman's equality of educational opportunity data. Teach Coll Rec, 112(5): 12011246.

Cheema, J.R. \& Kitsantas, A. (2014) Influence of disciplinary classroom climate on high school student self-efficacy and mathematics achievement: A look at gender and racial ethnic differences. Int J Sci Math Educ, 12(5): 1261-1279.

Conwayturner, J. (2016) Does diversity matter? The impact of school racial composition on the academic achievement of elementary school students in an ethnically diverse low- income sample. Dissertation of George Mason University.

Downey, D.B. \& Condron, D.J. (2016) Fifty years since the Coleman report: Rethinking the relationship between schools and inequality. Sociol Educ, 89(3): 207-220.

Downey, D.B., Hippel, P.T.V. \& Broh, B.A. (2004) Are schools the great equalizer? Cognitive inequality during the summer months and school year. Am Sociol Rev, 69(5): 613-635.

Downey, J. A. (2008) Recommendations for fostering educational resilience in the classroom. Prev Sch Fail, 53(1): 56-64.

Du, P. \&Yang, Z.C. (2012) Research on school effectiveness and it's influencing factors: An application of the Creemers' comprehensive model of school effectiveness in China. Education \& Economy, 2: 45-50.

Finn, J.D. \&Achilles, C.M. (1999) Tennessee's class size study: Findings, implications, misconceptions. Educ Eval Policy An, 21(2): 97-109.

Gustafsson, J.E., Nielsen, T. \& Hansen, K.Y. (2016) School characteristics moderating the relation between student socio-economic status and mathematics achievement in Grade 8: Evidence from 50 countries in TIMSS 2011. Stu Educ Eval, 57: 16-30.

He, M.J. (2013) On characters of migrant and left-behind resilient students and the predicted effect of these characters on academic resilient outcome. Dissertation of Beijing Normal University.

He, M.J., Yang, T. \& Xin, T. (2016) Mentality $\times$ resources: the key influencing factors of primary migrant and left-behind children's academic achievement -- based on the research of 8,590 fourth-grade primary school students in China. Elementary and Middle School Administration, (11): 27-31.

Heyneman S.P. \&Loxley, W.A. (1983) The effect of primary school quality on academic achievement across twenty-nine high- and low-income countries. Am J Sociol, 88(6): 1162-1194.

Hou, Y.N. \&Shen, A.X. (2014) The impact of school resources on quality \& equality of basic education in shanghai: Empirical study based on PISA2009, Educ Res Mon, 9: 3845. 
Kahlenberg, R.D. (2013) From all walks of life: New hope for school integration. Am Educ, 36(2): 2-14.

Klieme, E. , Hu, Y.M. \& Peng, P. (2014) The application of international large-scale assessment on educational effectiveness research: The theory, methodology and limitations. Educ Res, 3: 39-47.

Klieme, E., Pauli, C. \& Reusser, K. (2009) The Pythagoras study: Investigating effects of teaching and learning in Swiss and German mathematics classroom. In T. Janik \& T. Seidel (Eds.), The power of video studies in investigating teaching and learning in the classroom (pp. 137-160). Münster, Germany: Waxmann.

Konstantopoulos, S. \& Chung, V. (2011) Teacher effects on minority and disadvantaged students' grade 4 achievement. J Educ Res, 104(2): 73-86.

Lee, V.E., Winfield, L.F. \& Wilson, T.C. (1991) Academic behaviors among high-achieving African American students. Educ Urb Soc, 24(1): 65-86.

Li, H.L. \& Zhang, W.X. (2006) Review of the studies on psychological resilience. J Shandong Nor Uni (Hum Soc Sci), 51(3): 149152.

Lian, Y.J. \& Liao, J.P. (2017) How to test the inter-group coefficient difference after group regression? J Zhengzhou Univ Aero, 35(6): 97-109.

Longobardi, S. \&Agasisti, T. (2014) Educational institutions, resources, and students' resiliency: An empirical study about OECD countries. Econ Bull, 34(2): 1055-1067.

Manski, C.F. (1993) Identification of endogenous social effects: The reflection problem. Rev Econ Stu, 60(3): 531-542.

Ndlovu, N. (2018) School resources and student achievement: A study of primary schools in Zimbabwe. Educ Res Rev, 13(7): 236-248.

Nye, B., Konstantopoulos, S. \&Hedges, L.V. (2004) How large are teacher effects? Educ Eval Policy An, 26(3): 237-257.

OECD. (2005) School factors related to quality and equity: Results from PISA 2000. Paris: OECD Publishing.

OECD. (2011) Against the odds: Disadvantaged students who succeed in school. Paris: OECD Publishing.
OECD. (2018) Equity in education: Breaking down barriers to social mobility. Paris: OECD Publishing.

Palardy, G.J. (2013) High school socioeconomic segregation and student attainment. Am Educ Res J, 50(4): 714-754.

Perry, L.B. \& McConney, A. (2010) Does the SES of the school matter? An examination of socioeconomic status and student achievement using PISA 2003. Teach Coll Rec, 112(4): 7-8.

Perry, L.B. (2012) What do we know about the causes and effects of school socio-economic composition? A review of the literature. Educ Soc, 30(1): 19-35.

$\mathrm{Pu}, \mathrm{X} . W$. (2016) Effect sizes in quantitative analysis: Significance, computation and interpretation. Psyc Expl, 36(1): 64-69.

Raudenbush, S.W. \& Eschmann, R.D. (2015) Does schooling increase or reduce social inequality? Annu Rev Sociol, 41(1): 443-470.

Ready, D.D. (2010) Socioeconomic disadvantage, school attendance, and early cognitive development: The differential effects of school exposure. Sociol Educ, 83(4): 271286.

Ren, C.R. \&Xin, T. (2011) Responsibilities of schools in the process to achieve learning outcome equity: A perspective from the impacts of schools on students outcome. J Sch Stu, 8(2): 30-35.

Roorda, D.L., Koomen, H.M. \&Spilt, J.L., et al., (2011) The influence of affective teacherstudent relationships on students' school engagement and achievement: A meta-analytic approach. Rev Educ Res, 81(4): 493-529.

Ross, C.E. \& Mirowsky, J. (2006) Sex differences in the effect of education on depression: Resource multiplication or resource substitution? Soc Sci Med, 63(5): 1400-1413.

Rumberger, R. \& Palardy, G. (2005) Does segregation still matter? The impact of student composition on academic achievement in high school. Teach Coll Rec, 107(9): 19992045.

Sosa T. \&Gomez, K. (2012) Connecting teacher efficacy beliefs in promoting resilience to support of Latino students. Urb Educ, 47(5): 876-909.

Southworth, S. (2010) Examining the effects of school composition on North Carolina stu- 
dent achievement over time. Educ Policy An Arc, 18(29): 1-45.

Vanlaar, G., Kyriakides, L. \& Panayiotou, A., et al., (2016) Do the teacher and school factors of the dynamic model affect high- and lowachieving student groups to the same extent? A cross-country study. Res Pap Educ, 31(2): 183-211.

Voight, A., Austin, G. \&Hanson, T. (2013) A climate for academic success: How school climate distinguishes schools that are beating the achievement odds. San Francisco, CA: West Ed.

Wang, D.D. \& Zhou, J.X. (2017) Effects of poverty on structure and function of brain and educational intervention, J Bio Educ, 5(1): 47-54.

Wang, M.C., Haertl, G.D. \& Walberg, H.J. (1998) Building educational resilience. Phi Delta Kappa, 30: 1-64.

Waxman, H.C., Huang, S.L. \& Wang, M.C.

(1997) Investigating the multilevel class- room learning environment of resilient and non-resilient students from inner-city elementary schools. Int J Educ Res, 27(4): 343353.

Waxman, H.C., Padrón, Y.N. \&Shin, J.Y., et al. (2008) Closing the achievement gap within reading and mathematics classrooms by fostering Hispanic students' educational resilience. Int J Soc Sci, 3(1): 641-651.

Wu, Y.X. \& Huang, C. (2016) Stratification of the School Hierarchy and Educational Expectations of Students in Basic Education. Soc Sci China, (4): 111-134.

Xie, G.H. \& Zhang, Y.Y. (2018) School of golden touch? A study of school's effectiveness in improving students' academic performance. Soc Stu, (3): 141-165+245.

Zimmer, R.W. \& Toma, E.F. (2000) Peer effects in private and public schools across countries. J Policy Man, 19(1): 75-92

Received: 6 June 2019

Revised: 25 June 2019

Accepted: 17 July 2019

The Chinese version of this article has been published in China Economics of Education Review, 2019; 4(2):3-25. The English version has been authorized for being publication in BECE by the author(s) and the Chinese journal.

张平平, 胡咏梅. 家庭处境不利学生如何实现学业成绩的逆袭: 学校在其中的作用. 教育经 济评论, 2019; 4(2):3-25. 